\section{The relation between entrepreneurship and rural poverty alleviation in China}

Rural poverty alleviation

Eric Yaw Naminse

School of Economics and Management, Qinzhou University, Qinzhou, China and School of Management, Jiangsu University, Zhenjiang, China

Jincai Zhuang

School of Management, Jiangsu University, Zhenjiang, China, and

Fangyang Zhu

School of Economics and Management, Qinzhou University, Qinzhou, China

\begin{abstract}
Purpose - There is a recent growing interest to find a lasting intervention to rural poverty (RP) in developing countries based on farmer entrepreneurship and innovation. The purpose of this paper, therefore, is to examine the relation between entrepreneurship and RP alleviation in two resource-constrained provinces of China. This paper assesses the influence of three capabilities of farm entrepreneurs - educational, economic and socio-cultural - on farmer entrepreneurship growth and how these, in turn, impact alleviation of RP.

Design/methodology/approach - Household survey data comprising 363 respondents were taken from four deprived communities in two provinces of China. The paper employed structural equation modeling (SEM), using AMOS 21.0 alongside SPSS 20.0 to test the relations between the constructs.

Findings - The results show that a statistically significant and positive relation exists between entrepreneurship and RP alleviation in China. The findings of the study further reveal that qualitative growth of entrepreneurship has a stronger positive influence on RP alleviation than on quantitative growth, and socio-cultural capabilities of respondents significantly and positively affect entrepreneurial growth of farmers, rather than education and economic capabilities.

Research limitations/implications - The use of data from four communities in two provinces tends to limit the ability to generalize the findings of the study. Furthermore, the survey did not collect information on non-farm entrepreneurs, making it impossible to compare the findings from farm entrepreneurs with non-farm entrepreneurs.

Practical implications - The findings have practical implications for policy makers in rural China toward addressing targeted RP. This paper, therefore, suggests that entrepreneurship should be pursued vigorously among farmers in rural areas of China to help solve poverty. The paper also presents a useful lesson for various stakeholders in poverty alleviation programs in other developing countries.

Originality/value - This paper contributes to the academic literature on the entrepreneurship-RP alleviation nexus by combining the theory of capability and SEM in the analysis of an emerging economy such as China.
\end{abstract}

Keywords China, Structural equation modelling, Capability approach, Rural poverty,

Farmer entrepreneurship

Paper type Research paper

\section{Introduction}

Recent years have been witnessing a growing interest in finding a lasting intervention to rural poverty (RP) alleviation in developing countries and in entrepreneurship, which is regarded as one of the most important drivers of economic growth in many nations

\footnotetext{
(C) Eric Yaw Naminse, Jincai Zhuang and Fangyang Zhu. Published by Emerald Publishing Limited. This article is published under the Creative Commons Attribution (CC BY 4.0) licence. Anyone may reproduce, distribute, translate and create derivative works of this article (for both commercial and non-commercial purposes), subject to full attribution to the original publication and authors. The full terms of this licence may be seen at http://creativecommons.org/licences/by/4.0/legalcode
}

2593

Received 22 November 2017 Revised 6 August 2018 2 November 2018 Accepted 6 November 2018

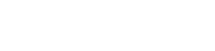


$\mathrm{MD}$

57,9

2594

(Acs et al., 2005; Gómez-Grass et al., 2010; Seuneke et al., 2013; Shane and Venkataraman, 2000; Thurik et al., 2008) and appears to have positively impacted poverty reduction and sustainable development (Dhahri and Omri, 2018; Yanya et al., 2013). The role of agriculture in sustainable economic growth and rural development in developing economies, including China, also cannot be overemphasized as more farmers are engaged in entrepreneurial activities through innovation, to create employment opportunities for themselves and rural communities (Ge et al., 2015; Syed et al., 2012; Zhao and Tang, 2018). Thus, entrepreneurship has often been an integral part of the agriculture sector to increase returns and reduce poverty in developing countries (Van Rooyen, 2014).

Meanwhile, farmer entrepreneurship (measured by newly founded farm enterprises) has, in recent times, been found to have positively impacted conflict resolution and poverty reduction in developing nations (Bruton et al., 2013; Hoang et al., 2014; Tobias et al., 2013). For instance, according to Fitz-Koch et al. (2018), entrepreneurship in the agricultural sector needs to be given much attention due to the promising opportunities it has contributed to the theoretical and empirical analyses of entrepreneurship research. Carter et al. (2017) also emphasized that farmer entrepreneurship research should focus more on household activities of individuals and their communities.

Although there exists a large body of scholarly work on entrepreneurship and poverty in China (Cai et al., 2018; Li and Wu, 2014; Zheng and Zhao, 2017), empirical findings on the relationship between farmer entrepreneurship and RP alleviation still appear to be scant. This paper thus focuses mainly on the emerging trend of many rural farmers becoming entrepreneurs and how RP is being effectively addressed. The paper, therefore, mainly examines how three capabilities of farm entrepreneurs, namely, educational, economic and socio-cultural, impact the growth of farmer entrepreneurship (quantitatively and qualitatively) and to what extent the growth of farmer entrepreneurship has affected RP alleviation in China, using the capability theory. This study is important because RP in China continues to be a critical challenge facing the central government and its quest to improve the living conditions of many rural dwellers, and it is worth exploring this new phenomenon of farmer entrepreneurship. Currently, as the second largest economy in the world, China's level of RP appears to be on the increase, and this affects millions of people, especially rural farmers and their families. China has made tremendous contributions to global poverty reduction, where the national poverty rate dropped from 88 percent in 1978 to approximately 6.5 percent in 2012 , as measured by the percentage of individuals living on the equivalence of $\$ 1.90$ or less per day in terms of 2011 purchasing power parity (World Bank, 2013). This remarkable progress in poverty reduction in China can be attributed to the government's commitment and emphasis on ensuring sustainable economic growth through agricultural activities over the last three decades, making the agriculture sector play a key strategic role in reducing RP (Montalvo and Ravallion, 2010; Ravallion and Chen, 2007). However, there are still approximately $70 \mathrm{~m}$ people living below the national RP line of CNY 2,300/year or US\$376/year (Xinhua News, 2015). Several attempts have been made to alleviate RP in China. These include the National Poverty Reduction Program initiated for implementation from 1994 to 2000 (Wang et al., 2004); the Entire-Village Advancement or the Targeted Poverty Alleviation strategy, which ran from 2001 to 2010 (Wang and Chen, 2016); and, currently, the Development-Oriented Poverty Alleviation Program in Rural China (2011-2020). It is under this new pro-poor program that entrepreneurship has been highlighted as part of the strategies targeted at reducing RP. Therefore, despite attempts to alleviate RP in China over the years, the problem persists, giving rise to stakeholders who wonder what the cause might be since the economic gains of the country appear not to have been evenly distributed.

$\mathrm{RP}$ is a multidimensional phenomenon and cannot be solved using a single strategy. RP includes not only income poverty but also limited access to quality education, healthcare, 
potable water and energy supply, and most of the rural poor in China live in remote and mountainous areas. Meanwhile, entrepreneurship is viewed as a tool for boosting economic growth in developed and developing countries, which can impact poverty reduction (Bruton et al., 2013). However, there is little investigation of the role of farmer entrepreneurship on $\mathrm{RP}$ alleviation in China. Researchers in entrepreneurship and poverty studies have focused on mature economies that have fewer issues involving RP.

Therefore, this paper employs the capability theory of Sen (1981), which emphasizes the importance of human capabilities on poverty alleviation, to investigate the link between farmer entrepreneurship and RP in China. The main objectives are: to determine which capabilities of farm entrepreneurs greatly affect the growth of farmer entrepreneurship; to assess how farmer entrepreneurship impacts RP; and to make policy recommendations to China's Government for a sustainable pathway to RP alleviation. This paper will make a modest contribution to the literature on RP and farmer entrepreneurship in China by combining the capability approach (CA) and structural equation modeling (SEM). Furthermore, the experience of China in RP alleviation can be a lesson for other developing countries toward achieving the first target of the sustainable development goals, ending poverty in all its forms everywhere by 2030 .

This paper is organized into six sections. Following the introduction, the review of relevant literature is next, while the theory and hypotheses development is presented in the third section. This is followed by the methodology, which includes the study areas, sample size and sampling techniques employed in the data collection and method of analysis. The fifth section contains the results and detailed discussions, while the final section presents the conclusions, study limitations and suggestions for future research.

\section{Review of related literature}

According to the Global Entrepreneurship Monitor studies, entrepreneurship has become an essential tool for job and wealth creation, which highlights the relationship between economic growth and entrepreneurship (Acs et al., 2005; Gómez-Grass et al., 2010; Seuneke et al., 2013; Shane and Venkataraman, 2000; Thurik et al., 2008). Entrepreneurship is defined as a multidimensional concept (Verheul et al., 2002), involving a range of business activities from the process of "creative destruction" (Schumpeter, 1934) to innovative creation of additional value for an existing or "new organization" (Harbi and Anderson, 2010). Entrepreneurship is also defined as an attempt at new business or venture creation, such as self-employment, new business organization, or the expansion of an existing business, by an individual, a team of individuals, or an established business (Global Entrepreneurship Monitoring Report, 2014). More importantly, in recent times, entrepreneurship is seen as a pathway to reducing poverty and conflicts in developing countries (Bruton et al., 2013; Sutter et al., 2018; Tobias et al., 2013). This underscores the need for investigation of the relationship between farmer entrepreneurship and RP.

In the conceptualization of farmers as entrepreneurs, farming is no longer regarded as a way of life but a business enterprise capable of transforming rural living conditions. A farmer who starts a business in addition to the main on-farm work, where the activities are different from the traditional farming activities of cultivating the soil, growing crops and rearing livestock as the main source of income and livelihood, is regarded as a farm entrepreneur (McElwee, 2004).

With many studies on entrepreneurship as an academic field (Shane and Venkataraman, 2000; Walter and Block, 2016), research on farmer entrepreneurship is still largely new to many scholars. As a relatively new concept, farmer entrepreneurship has varied definitions. It is often linked with self-employment and/or farm and non-farm activities that people undertake to earn a living. In this paper, farmer entrepreneurship is defined based on the value addition of farm products by farmers engaged in other non-farm business to augment earnings. 
$\mathrm{MD}$

57,9

2596

For the literature on poverty, various meanings and dimensions exist, which can either be RP or urban poverty (Alkire and Santos, 2014; Venot, 2016). In China, studies show that the poor are predominantly located in the rural areas and poverty is more pronounced among ethnic minority groups. The poor are characterized by extreme social exclusion and lack of human capabilities to enable them access to job opportunities within their localities. $\mathrm{RP}$ may also be persistent in China due to limited infrastructural development in education, healthcare, access to roads, potable water and electricity in the deprived and mountainous regions (She et al., 2018; Tortajada, 2016; Wan and Zhang, 2018). According to She et al. (2018), lack of optimal infrastructural development in mountainous townships in Southwest China has affected economic performance to a large extent over the years. The exodus of young people from rural communities to larger cities in search of higher-earning jobs also leaves much to be desired, leading to a shortage in human capital development and fewer resources for investment (Meng and Zhao, 2017). Furthermore, although it may be too early to assess the impact of China's "One Belt One Road" initiative on economic development in the rural areas that the initiative passes through, it appears there is less involvement of rural communities along the "Belt and Road" regions to turn their underdevelopment into new vibrant economic societies through infrastructural investments (Huang, 2016; Zhai, 2018).

As a multidimensional concept (Chowdhury and Mukhopadhaya, 2012; Ravallion, 2011), poverty is considered a condition in which people are economically, culturally, educationally and environmentally disadvantaged. Rowntree (1901) defines the poor as people whose daily income expenditure fell below a calculated weekly sum of money required to enable their families to secure the necessity of a healthy life. Hunter (1904), who also studied poverty in the USA, argued that there were more than $10 \mathrm{~m}$ persons in America living in poverty, and attempted to define and measure poverty.

Research has widened the meaning of poverty to include non-income factors required to maintain a minimum standard of living. The multidimensionality of poverty is therefore no longer debatable (Aaberge and Brandolini, 2015) but is a concept that incorporates economic, social, cultural and human capability theory. According to May (1999), poverty is the inability of individuals, households or an entire community to command sufficient resources to satisfy a socially acceptable minimum standard of living. Among all these definitions, it is the understanding of poverty by Sen (1981) that this paper adopts because it is widely linked to human development activities prescribed by UNDP annual reports. Poverty also refers to the lack of human capabilities or entitlements to ensure that freedom and justice are attained (Sen, 1981). RP, on the other hand, refers to human deprivation that takes place in nonmetropolitan areas with a population below 50,000 and where there are more single-guardian households, less access to public service and support for disabilities, and limited education and healthcare opportunities. In this paper, we define RP as the lack of economic, socio-cultural and educational capabilities of farmers to be able to convert opportunities into profitable business ventures to improve their living conditions.

Role of farmer entrepreneurship in rural development and poverty alleviation. The development or revitalization of rural areas in many countries has become a new growth point of rural economies in China and other regions. Under the new normal in China, farmer entrepreneurship is a new strategy meant to advance rural urbanization, revitalize the rural economy and solve poverty. This is because it has been found that farmer entrepreneurship is capable of effectively stimulating rural industrialization since it is able to help farmers increase their incomes and improve their standard of living. Farmers involved in entrepreneurial activities are therefore more likely to overcome RP faster than non-farm entrepreneurs in developing countries (Nagler and Naudé, 2017). As a result of the above phenomenon, most Chinese agricultural policies have strongly focused on the development of entrepreneurship in the countryside with the aim to reduce poverty. For instance, village enterprise programs over the years have encouraged the growth of entrepreneurship and 
innovation as a means of addressing extreme poverty in deprived areas. Even though the persistence of RP in China is a multifaceted issue, the Chinese rural poor basically have limited access to public goods such as education, healthcare, housing, roads and meaningful employment to improve their living conditions.

At present, some scholarly works on farmer entrepreneurship in China and other countries exist (Bao et al., 2016; Carter, 1999; Kahan, 2012; McElwee, 2006; Pyysiäinen et al., 2005; Rudmann, 2008; Sharma et al., 2010), and the findings of these studies have shown that farmer entrepreneurship has the potential to improve the living conditions of resource-poor alleviation farmers in rural areas. For instance, Saxena (2012) intimated that farmer entrepreneurship in India plays a key role in increasing per capita income through the creation of rural jobs. The study found that farmer entrepreneurship has helped to achieve higher productivity in farm and non-farm businesses and assisted in reducing the migration of young people from the rural areas to urban centers. Although the literature on farmer entrepreneurship in China is still growing, a recent study by Yuan et al. (2017), using 219 observations taken from Zhejiang Province and based on Grounded Theory, revealed that many Chinese farmers have been turning to entrepreneurial activities as an alternative way to earn higher incomes to improve their living standards.

Therefore, farmer entrepreneurship is now becoming accepted as a rural economic development strategy, helping communities and small towns to design and implement mechanisms aimed at reducing poverty. This role played by farmer entrepreneurship to transform rural economies presents a unique opportunity to local governments, researchers and other stakeholders in China to consider pooling scarce resources to confront the status quo of the "top-down" approach to RP alleviation and help rural farmers develop and own businesses that will help create jobs, increase rural economic growth and help lift many more people off the bottom of the economic ladder in the country.

\section{Theory and hypotheses development}

The concept of the CA, according to Robeyns (2005), is a broad normative framework used for evaluating, measuring and assessing the well-being of individuals in order to help formulate policies and programs to effect the socioeconomic transformation of societies. The causes of RP can be varied and wide, but many scholars attribute the incidence of RP to lack of basic human capabilities to convert opportunities by "smart" individuals (entrepreneurs) into profitable business ventures. The CA was developed by Sen (1981), and it seeks to measure human well-being from the perspective of expansion of people's capabilities and not just the maximization of utility or income.

The CA mainly focuses on the functions or living conditions of individuals and defines them as "what people can do or cannot do, or what they can or cannot be" (Sen, 1985). This is concerned with the ability of persons to achieve freedom of development. Since its introduction into mainstream research as a method for measuring poverty, inequality and distribution justice in social theory, the United Nations has adopted it for the annual Human Development Reports (HDR) since 1990 (UNDP, 2010). Shepherd (2015) identifies the need to explore entrepreneurial opportunities that build on identifying people's capabilities to create businesses to help alleviate poverty. Greco et al. (2015) evaluated a community-based participatory intervention that sought to improve maternal health in rural Malawi using the CA. They realized that the quality of rural women's lives is shaped by social relations and norms of society. Based on the wide use of the $\mathrm{CA}$, this paper adopts the approach to examine how farmer entrepreneurship affects RP in China.

In this paper, three capabilities of farm entrepreneurs, namely, education, economic and socio-cultural, are used to develop and test four hypotheses.

First, the role of education in helping lift residents from RP cannot be overemphasized (Mohapatra et al., 2007). The acquisition of knowledge and skills through education helps 
equip individuals for life-long improvement. Entrepreneurship and poverty are two important research areas where research findings show a strong link between education and poverty reduction. Verheul et al. (2015) indicate that education facilitates the accumulation of human capital for development and can also lead to improvement in entrepreneurial exploits by individuals. In rural China, poverty appears to be linked with the quality and level in education one attains. This is because education serves as one of the means through which people acquire knowledge, skills and experiences to gain employment for higher earnings. According to Mihai et al. (2015), the level of education and people's welfare are correlated with the latter improving substantially as the former increases. Aterido and Hallward-Driemeier (2011) examined the gender gap in entrepreneurship using data from Sub-Saharan Africa. They found that education had a positive link with higher productivity, which then influenced a reduction in poverty. Gökovali (2013) found that the welfare of households increases especially where mothers have formal education, with the impact being larger as the level of education increases. In this paper, educational capabilities of farm entrepreneurs refer to the availability of schools in the village, children's access to schools and farm entrepreneurs' willingness to contribute to the supply of public goods such as schools in their communities. Hence, we hypothesize the following:

H1a. There is a positive relation between educational capabilities of farm entrepreneurs and quantitative growth of farmer entrepreneurship.

H1b. There is a positive relation between educational capabilities of farm entrepreneurs and qualitative growth of farmer entrepreneurship.

Second, the literature on the relation between economic factors and entrepreneurship growth is found to be positive. For instance, Hoang et al. (2014), in a study on non-farm activities, household expenditure and poverty reduction in Vietnam, found that increased economic activities from non-farming activities help to reduce RP. China's experience of the transition from a command economy to a market-oriented economy following reforms and open-door policies (Tisdell, 2009) has enabled the people to overcome economic poverty to a large extent. However, farmers are still poor in the rural areas due to lack of enhanced jobs from the government. The private sector is one of the partners helping farmers in the rural areas to create jobs through support services to increase crop growing and rearing of animals. The need to engage farmers in vibrant economic activities requires the acquisition of economic skills by farmers. Economic capabilities of farm entrepreneurs are vital in determining the impact of farm activities on household well-being. These capabilities include marketing skills, management strategies and the use of modern technology to improve sales (Martin and Javalgi, 2016). Weaver et al. (2014) investigated the influence of four capabilities on stages of the innovation process using 264 survey data in China and realized that firms typically adopt management innovations facilitated by socioeconomic capabilities to improve a firm's performance. From the above, it is assumed that farm entrepreneurs' economic capabilities can help boost farm earnings. Based on this, this paper proposes the following:

H2a. There is a positive relation between economic capabilities of farm entrepreneurs and quantitative growth of farmer entrepreneurship.

$H 2 b$. There is a positive relation between economic capabilities of farm entrepreneurs and qualitative growth of farmer entrepreneurship.

Third, it is known that the social and cultural environments of individuals can affect innovation and entrepreneurial growth (Shane, 1993). According to Appadurai (2004), culture and traditions are rooted in society, and efforts to alleviate RP should consider the culture of the people. Social capabilities refer to the social structures in society such as the 
ability to have strong or weak networks with family members, friends, and peers at workplaces, while culture is the way of life of a group of people in a particular place at a particular time. Cultural values reflect how individuals interact with one another (Hofstede, 1980), and this affects human behavior. In China, culture is more collectivism than individualism, and this can have a great influence on entrepreneurial activities. Yuan and Zhou (2015) studied the effects of culture on group creativity, and they found that culture impacts group creativity by influencing individuals' cognitive tasks in management. Furthermore, Baron et al. (2016) examined how self-control in a socio-cultural context affects business performance. They found that self-control encourages entrepreneurs to set attainable goals. According to Ferreira et al. (2015), social networks and cultural values serve as drivers of innovation in business growth. The socio-cultural capabilities (SSC) of farm entrepreneurs examined in this paper include a democratic environment (freedom of expression), transparency in the management of village issues, and openness in decision-making processes. To enhance human well-being, freedom and improved culture, participation in open decision-making, can promote farm entrepreneurial activities. Therefore, we hypothesize the following:

H3a. There is a positive relation between SSC of farm entrepreneurs and quantitative growth of farmer entrepreneurship.

$H 3 b$. There is a positive relation between $\mathrm{SSC}$ of farm entrepreneurs and qualitative growth of farmer entrepreneurship.

Fourth, there is a strong evolving link between entrepreneurship and poverty reduction in developing countries (Martinez et al., 2015; Ngoasong and Kimbu, 2016). Although existing literature does not have enough empirical evidence establishing a relationship between farmer entrepreneurship and RP, it is expected that the two issues could be related since the majority of the world's poor live in rural areas, subsisting on agriculture as their mainstay, which involves entrepreneurship (Birthal et al., 2015). In China, Montalvo and Ravallion (2010) discovered that agriculture is the main contributor to poverty reduction. Démurger and Fournier (2011) studied the relationship between rural households' economic wealth and firewood consumption in northern China and found that household economic wealth negatively impacts firewood consumption. Ansoms and McKay (2010) analyzed poverty and livelihood profiles in post-conflict rural Rwanda and found that RP can be approached through combined factors of natural, physical, human, financial and social resources/skills of farming household groups to improve their livelihoods.

In this paper, quantitative growth of farmer entrepreneurship refers to the number of farmers who become entrepreneurs, as well as the number of farm enterprises founded in the village. The qualitative growth of farmer entrepreneurship refers to how proceeds from farmer entrepreneurship are used to benefit individuals, households and communities. The quality of farmer entrepreneurship growth, therefore, is attributed to the kind of services rendered to the community by farm entrepreneurs. When farm entrepreneurs give back to their communities, it helps improve the living conditions of the entire community. For example, Li et al. (2014) examined how community-based land helped support agricultural villages in Henan Province of China. They realized that through community-based business practices, rural living conditions improved markedly. Based on the above, this study hypothesizes the following:

H4a. The quantitative growth of farmer entrepreneurship has a positive influence on $\mathrm{RP}$ alleviation.

$H 4 b$. The qualitative growth of farmer entrepreneurship has a positive influence on $\mathrm{RP}$ alleviation. 


\section{Methodology}

\section{Sample and data collection}

This study mainly examines the relation between entrepreneurship among farmers and $\mathrm{RP}$ alleviation in China using a total of 363 primary data from Guangxi and Zhejiang provinces. A semi-structured questionnaire was used to conduct the interviews in 2016. With a total of 416 questionnaires administered, 363 were returned, representing a retrieval rate of 87.26 percent. While purposive sampling was used to select the two provinces and four farming communities, snowball sampling was used to choose the 363 employees for face-to-face interviews. A five-point Likert scale was used to measure the quality of life satisfaction and the contribution of the farmers toward the improvement of their living conditions (Table AI).

\section{Study sites}

In Guangxi Province, data was collected from Baise, Guilin and Liuzhou communities. Guangxi Province has a land area of $236,700 \mathrm{~km}^{2}$, with approximately 12 indigenous ethnic groups. The region has a hot summer and cold winter coupled with dry and rainy periods, which make the place suitable for the cultivation of tropical and subtropical fruit crops such as gourd, mango, and banana, as well as vegetables such as tomato and eggplant. Annual temperature and rainfall average between $17^{\circ} \mathrm{C}$ and $23^{\circ} \mathrm{C}$, and $1,000 \mathrm{~mm}$ to $2,800 \mathrm{~mm}$, respectively (Wen et al., 2012). The data from Zhejiang Province were obtained from Wenzhou, which lies in the southeastern coast of the province and has many start-up businesses in seafood. Although Zhejiang is economically buoyant, Wenzhou was selected because it was one of the poorest communities in eastern China, dominated by migrant workers (Lin and Gaubatz, 2015). However, Wenzhou has developed to become an economic nerve center of Zhejiang Province due to the proliferation of farmer entrepreneurial activities. It had a population of approximately $7.99 \mathrm{~m}$ people in 2008 and a land area of $11,784 \mathrm{~km}^{2}$, with an annual rainfall of $1,800 \mathrm{~mm}$ and a mean temperature of $18^{\circ} \mathrm{C}$ (Ma et al., 2015).

\section{Data analysis method}

Based on the SEM, we employed SPSS 20.0 and AMOS 21.0 to conduct exploratory factor analysis (EFA) and confirmatory factor analysis (CFA) to obtain the reliability, validity, measurement and structural models.

\section{Results and discussion}

Socio-demographic characteristics of respondents

Table I shows the socio-demographic profile of the respondents. The results indicate that 82.64 percent of the respondents are young adults aged between 16 and 59 years. This is indicative that rural agriculture still serves as a major source of employment for the teeming youth in China. This finding is in contrast with that of Kong et al. (2015), who found that many rural areas in China have been deserted by the youth due to rural-urban migration. This finding, therefore, implies that farmer entrepreneurship can help reduce youth unemployment. In terms of gender, more males (62.26 percent) participate in farmer entrepreneurship, while the remaining 37.74 percent is female. This shows that although farmer entrepreneurship is still a male-dominated sector, feminization in agricultural is gradually taking place in China (de Brauw et al., 2008).

More women are being gainfully employed in farmer entrepreneurship, and this can lead to significant improvement in household living conditions because women are said to be better home managers. Further still, the education level of respondents shows that 51.79 percent of respondents reached the Junior High School level, 23.97 percent had 


\begin{tabular}{|c|c|c|c|c|}
\hline Variable & Description & Frequency & Percentage $(\%)$ & alleviation \\
\hline \multirow{4}{*}{ Age (years) } & $16 \sim 39$ & 148 & 40.77 & \\
\hline & $40 \sim 59$ & 152 & 41.87 & \\
\hline & $60 \sim 79$ & 58 & 15.98 & \\
\hline & 80 99 & 5 & 1.38 & \\
\hline \multirow[t]{2}{*}{ Gender } & Male & 226 & 62.26 & \\
\hline & Female & 137 & 37.74 & 2601 \\
\hline \multirow[t]{4}{*}{ Education level } & $\leqslant$ Primary & 87 & 23.97 & \\
\hline & JHS & 188 & 51.79 & \\
\hline & SHS/technical & 68 & 18.73 & \\
\hline & College/university & 20 & 5.51 & \\
\hline \multirow{2}{*}{ Marital status } & Married & 319 & 87.88 & \\
\hline & Not married & 44 & 12.12 & \\
\hline \multirow[t]{5}{*}{ Income/year } & 1,000 10K RMB & 54 & 14.88 & \\
\hline & $101 \mathrm{~K} \sim 400 \mathrm{~K}$ RMB & 203 & 55.92 & \\
\hline & $401 \mathrm{~K} \sim 800 \mathrm{~K}$ RMB & 13 & 3.58 & \\
\hline & $801 \mathrm{~K} \sim 1,200 \mathrm{~K}$ RMB & 72 & 19.83 & \\
\hline & 1,201K 10,000K RMB & 21 & 5.79 & \\
\hline \multirow[t]{4}{*}{ Occupation } & Farming only & 112 & 30.85 & \\
\hline & Farming and part-time work & 94 & 25.90 & \\
\hline & Part-time only & 25 & 6.89 & \\
\hline & Self-employed & 132 & 36.36 & Socio-demographic \\
\hline \multicolumn{2}{|c|}{$\begin{array}{l}\text { Notes: } n=363 . \text { US } \$ 1=6.2 \mathrm{RMB} \\
\text { Source: Authors' survey, } 2016\end{array}$} & & & $\begin{array}{r}\text { characteristics of } \\
\text { respondents }\end{array}$ \\
\hline
\end{tabular}

primary education, 18.73 percent reached the Senior High School or technical education level and 5.51 percent had college or university education. These findings confirm that education for Chinese rural residents has improved over the years, following the introduction of the nine-year compulsory universal basic education policy. The high levels of education mean new agricultural technologies can easily be adopted by farmers to improve agricultural productivity.

Farm entrepreneurs' incomes have also increased. For instance, 55.92 percent of respondents earn between US\$16,290 and US\$64,516 per annum. Additionally, 87.88 percent of respondents are married while 12.12 percent are unmarried. Self-employment is the dominant form of occupation by the people (36.36 percent), followed by farming only (30.85 percent). Rural incomes of respondents are in the ranges of 101,000-40,000 RMB per annum.

\section{Descriptive statistics}

Table II presents the results of the EFA using principal component and common factor analysis CFA.

EFA was performed to determine the factor loadings of the constructs and to estimate the reliability and validity of the data based on the results of the Cronbach's $\alpha$ coefficients. Following the EFA, three items (11, 14 and 20) were dropped due to their poor factor loadings. The Cronbach's $\alpha$ values ranged from 0.75 to 0.91 , and were applied to test the reliability of each construct (Nunnally, 1978).

\section{Structural model}

Figure 1 shows the structural model, which displays the effects of the relationship among the latent variables and the constructs.

It can be seen that all the estimates are positive and significant, except the effect of education capabilities (EC1) on the quantitative growth of farmer entrepreneurship (FEQG1). 
$\mathrm{MD}$
57,9

Table II.

Means, standard deviations (SD) and reliability tests

\begin{tabular}{llcccc}
\hline Construct & Item & Mean & SD & CA $(\alpha)$ & Factor loadings \\
\hline FEQG1 & y1 & 3.91 & 1.12 & 0.89 & 0.96 \\
FEQG2 & y2 & 3.54 & 1.24 & & 0.84 \\
EC1 & y3 & 2.85 & 1.33 & 0.75 & 0.77 \\
& y4 & 3.43 & 1.14 & & 0.74 \\
& y5 & 3.91 & 1.14 & 0.80 & 0.67 \\
EC2 & y6 & 3.91 & 1.05 & & 0.87 \\
& y7 & 3.96 & 1.05 & & 0.76 \\
& y8 & 3.22 & 1.21 & 0.91 & 0.85 \\
SCC & y9 & 3.17 & 1.17 & & 0.89 \\
& y10 & 2.95 & 1.28 & & 0.85 \\
& y16 & 3.35 & 1.18 & 0.85 & 0.91 \\
RP & y17 & 3.35 & 1.17 & & 0.64 \\
& y18 & 3.54 & 1.07 & & 0.91 \\
& y12 & 3.28 & 1.12 & 0.83 & 0.89 \\
& y13 & 3.22 & 1.11 & & 0.65 \\
& y15 & 3.64 & 1.00 & & 0.58
\end{tabular}

Notes: FEQG1, farmer entrepreneurship quantitative growth; FEQG2, farmer entrepreneurship qualitative growth; EC1, education capabilities; EC2, economic capabilities; SCC, socio-cultural capabilities; RP, rural poverty; CA, Cronbach's alpha $(\alpha)$
Figure 1.

Structural equation model

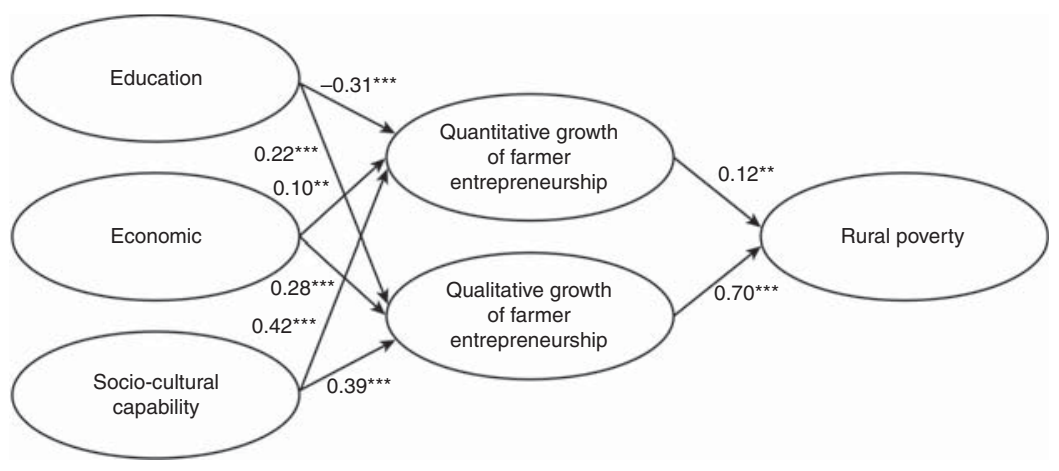

Notes: ${ }^{*} p<0.05 ; * * p<0.01 ; * * * p<0.001$

Source: Authors' construct, 2016

Thus, the effect of EC1 on FEQG1 is negative $(\beta=-0.31)$ and that of EC1 on FEQG2 is positive $(\beta=0.22)$, while the effect of EC2 on FEQG1 is positive $(\beta=0.10)$ and the effect of EC2 on FEQG2 is positive as well $(\beta=0.28)$. The impact of SCC on farmer entrepreneurship quantitative growth (FEQG1) is positive and significant $(\beta=0.42, p<0.01)$, and the effect of SCC on FEQG2 is also positive and statistically significant $(\beta=0.39, p<0.01)$. The results indicate that SCC of farm entrepreneurs have a stronger positive impact on farmer entrepreneurship growth than education (EC1) and economic capabilities (EC2). Second, the qualitative growth of farmer entrepreneurship (FEQG2) positively and more significantly impacts $(\beta=0.70) \mathrm{RP}$ than quantitative growth (FEQG1) impacts $\mathrm{RP}(\beta=0.12)$. This finding is also in line with Kantur (2016), who found that there is a positive relationship between entrepreneurial orientation and performance. It further indicates that the willingness of farm entrepreneurs to contribute toward the supply of essential public goods and services helps to alleviate RP rather than merely the proliferation of farm enterprises. The education 
capabilities of farm entrepreneurs also have a significant positive effect on the qualitative growth of farmer entrepreneurship and this impacts positively on RP. This finding is in line with Tarabini and Jacovkis (2012), who found that there is a link between education and poverty reduction. There also exists a significant and positive relation between the quantitative and qualitative growth of farmer entrepreneurship $(\beta=0.62)$. Thus, care needs to be taken when implementing policies meant to improve farmer entrepreneurship growth, to avoid trade-offs between quantitative and qualitative growth benefits.

\section{Measurement model}

The model was tested according to Gerbing and Anderson (1988), and with the results of the CFA, the standardized coefficients and other fit statistics were used to assess the model. Table III shows the findings, where all the factor loadings except items y5 (0.67) for education capabilities construct, y15 (0.63) and y19 (0.58) for RP construct exceeded 0.7 (Carmines and Zeller, 1979). The convergent validity indicates the extent to which all items in a construct measure the same concept as determined by the average variance extracted (AVE). The results of AVE for the constructs are also within the threshold of 0.5 (Fornell and Larcker, 1981), while the composite reliability values are within the acceptable range of 0.7 (Hair et al., 2006), which indicates a good measure of internal consistency of the constructs (Bagozzi and Youjae, 1988).

The fit indices were within acceptable standards $\left(\chi^{2} / \mathrm{df}=2.63, \mathrm{GFI}=0.85, \mathrm{AGFI}=0.91\right.$, $\mathrm{RMSEA}=0.04, \mathrm{CFI}=0.89$ and $\mathrm{NFI}=0.85)$ for the three capabilities' constructs $(\mathrm{EC} 1, \mathrm{EC} 2$ and SCC). For the farmer entrepreneurship quantitative and qualitative growth (FEQG1 and FEQG2), the fit statistics are $\chi^{2} / \mathrm{df}=2.52, \mathrm{GFI}=0.93, \mathrm{AGFI}=0.91, \mathrm{RMSEA}=0.05$, $\mathrm{CFI}=0.84$ and $\mathrm{NFI}=0.77$. For the RP constructs, the fit indices are $\chi^{2} / \mathrm{df}=2.71, \mathrm{GFI}=0.85$, $\mathrm{AGFI}=0.89$, RMSEA $=0.04, \mathrm{CFI}=0.90$ and $\mathrm{NFI}=0.80$. According to Bentler (1992), GFI, AGFI, CFI and NFI should not be less than 0.90, and RMSEA $\leqslant 0.05$ is acceptable (Bentler, 1990). The overall model fit is therefore satisfactory.

\begin{tabular}{|c|c|c|c|c|c|c|c|c|c|c|c|}
\hline Construct & Item & $\mathrm{SE}$ & $p$-value & $\mathrm{CR}$ & AVE & $\chi^{2} / \mathrm{df}$ & GFI & AGFI & RMSEA & $\mathrm{CFI}$ & NFI \\
\hline $\mathrm{EC} 1 \rightarrow$ & y5 & 0.20 & $0.000^{* * * *}$ & 0.81 & 0.59 & 2.63 & 0.85 & 0.93 & 0.04 & 0.87 & 0.85 \\
\hline $\mathrm{EC} 1 \rightarrow$ & y6 & 0.20 & $0.000^{* * * *}$ & & & & & & & & \\
\hline $\mathrm{EC} 1 \rightarrow$ & y7 & 0.20 & $0.000^{* * * *}$ & & & & & & & & \\
\hline $\mathrm{EC} 2 \rightarrow$ & y8 & 0.35 & $0.000^{* * * *}$ & 0.89 & 0.74 & 2.52 & 0.82 & 0.81 & 0.05 & 0.93 & 0.90 \\
\hline $\mathrm{EC} 2 \rightarrow$ & y9 & 0.35 & $0.000^{* * * *}$ & & & & & & & & \\
\hline $\mathrm{EC} 2 \rightarrow$ & $\mathrm{y} 10$ & 0.35 & $0.000^{* * * *}$ & & & & & & & & \\
\hline $\mathrm{SCC} \rightarrow$ & y16 & 0.28 & $0.000^{* * * *}$ & 0.87 & 0.69 & 2.64 & 0.78 & 0.74 & 0.05 & 0.82 & 0.88 \\
\hline $\mathrm{SCC} \rightarrow$ & y17 & 0.28 & $0.000^{* * * *}$ & & & & & & & & \\
\hline $\mathrm{SCC} \rightarrow$ & y18 & 0.28 & $0.000^{* * * *}$ & & & & & & & & \\
\hline FEQG1 $\rightarrow$ & $\mathrm{y} 1$ & 0.39 & $0.000^{* * * *}$ & 0.88 & 0.82 & 2.65 & 0.93 & 0.91 & 0.04 & 0.80 & 0.91 \\
\hline FEQG1 $\rightarrow$ & y2 & 0.39 & $0.000^{* * * *}$ & & & & & & & & \\
\hline FEQG2 $\rightarrow$ & y3 & 0.23 & $0.000^{* * * *}$ & 0.67 & 0.51 & 2.75 & 0.73 & 0.84 & 0.05 & 0.75 & 0.84 \\
\hline FEQG2 $\rightarrow$ & $\mathrm{y} 4$ & 0.23 & $0.000^{* * * *}$ & & & & & & & & \\
\hline $\mathrm{RP} \rightarrow$ & y12 & 0.34 & $0.000^{* * * *}$ & 0.85 & 0.59 & 2.71 & 0.85 & 0.76 & 0.04 & 0.81 & 0.80 \\
\hline $\mathrm{RP} \rightarrow$ & y13 & 0.34 & $0.000^{* * * *}$ & & & & & & & & \\
\hline $\mathrm{RP} \rightarrow$ & y15 & 0.41 & $0.000^{* * * *}$ & & & & & & & & \\
\hline $\mathrm{RP} \rightarrow$ & y19 & 0.46 & $0.000 * * *$ & & & & & & & & \\
\hline
\end{tabular}

Notes: CR, composite reliability; AVE, average variance extracted; GFI, goodness-of-fit index; AGFI, adjusted goodness-of-fit index; RMSEA, root mean square error of approximation; CFI, comparative fit index; NFI, normed fit index are statistically significant at 0.05 level. Cut-off criteria: CR $\geqslant 0.07 ; \mathrm{AVE}>0.5 ; \chi^{2} / \mathrm{df}<5$; $\mathrm{GFI}>0.90 ; \mathrm{AGFI}>0.90 ; \mathrm{RMSEA}<0.08$; CFI $>0.90 ; \mathrm{NFI}>0.90 ; \mathrm{CA} \geqslant 0.5 . * p<0.05 ; * * p<0.01 ; * * * p<0.001$
Rural poverty alleviation

2603 
$\mathrm{MD}$

57,9

2604

Table IV.

Results of

hypotheses testing
Test of hypotheses

After the overall model indices were approved, hypotheses were tested via SEM, with the results shown in Table IV.

The results indicate that every path was significant at the $p=0.000$ level. Apart from the education capabilities, which had a negative effect on farmer entrepreneurship quantitative growth $(\beta=-0.31, t=-12.49)$, all the other paths had positive and significant effects. Therefore, all the hypotheses have been supported.

To further determine the overall impact of farmer entrepreneurship on RP alleviation, respondents were asked if they now earn more income from their activities than they did previously. The findings in Figure 2 show that 17.91 percent "Strongly Agreed" and 44.63 percent "Agreed," representing a total of 62.54 percent, which is evidence of improved earnings resulting from respondents' participation in farmer entrepreneurship. This finding is supported by Ying and Min (2011), who found that earnings from self-employed individuals help to improve the living conditions of rural farmers.

Again, respondents were asked how their earnings impacted their general living conditions, and Figure 3 shows that approximately 34.71 percent of respondents indicated "Agreed" and 16.53 percent "Strongly Agreed." This confirms that earnings from farmer entrepreneurship help the majority of farmers (51.24 percent) experience better living conditions by reducing poverty, and this is consistent with the tested hypotheses:

Do your earnings help to improve your living conditions?

\begin{tabular}{|c|c|c|c|c|}
\hline Path of hypothesis & Estimate $(\beta)$ & $t$-value & $p$-value & Support/not supported \\
\hline H1a: $\mathrm{EC} 1 \rightarrow \mathrm{FEQG} 1$ & -0.31 & -12.49 & $0.000^{* * * *}$ & Supported \\
\hline H1b: EC1 $\rightarrow$ FEQG2 & 0.22 & 5.29 & $0.000 * * *$ & Supported \\
\hline H2a: $\mathrm{EC} 2 \rightarrow \mathrm{FEQG} 1$ & 0.10 & 2.45 & $0.000 * *$ & Supported \\
\hline$H 2 b: \mathrm{EC} 2 \rightarrow \mathrm{FEQG} 2$ & 0.28 & 6.10 & $0.000 * * *$ & Supported \\
\hline$H 3 a: \mathrm{SCC} \rightarrow \mathrm{FEQG} 1$ & 0.42 & 10.75 & $0.000 * * *$ & Supported \\
\hline$H 3 b: \mathrm{SCC} \rightarrow \mathrm{FEQG} 2$ & 0.39 & 8.26 & $0.000 * * * *$ & Supported \\
\hline H4a: FEQG1 $\rightarrow \mathrm{RP}$ & 0.12 & 2.32 & $0.000 * *$ & Supported \\
\hline$H 4 b:$ FEQG2 $\rightarrow \mathrm{RP}$ & 0.70 & 19.53 & $0.000 * * * *$ & Supported \\
\hline
\end{tabular}

Figure 2.

Farmer entrepreneurship increases earnings

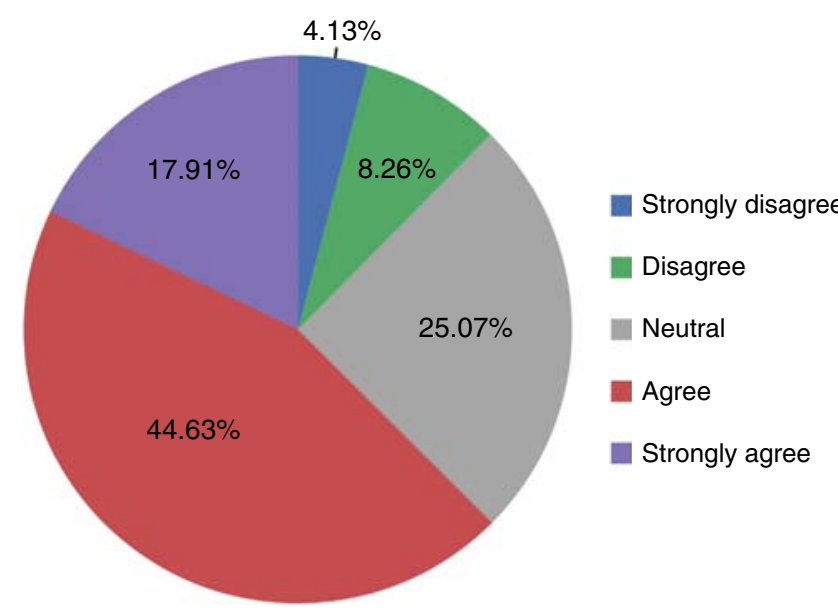




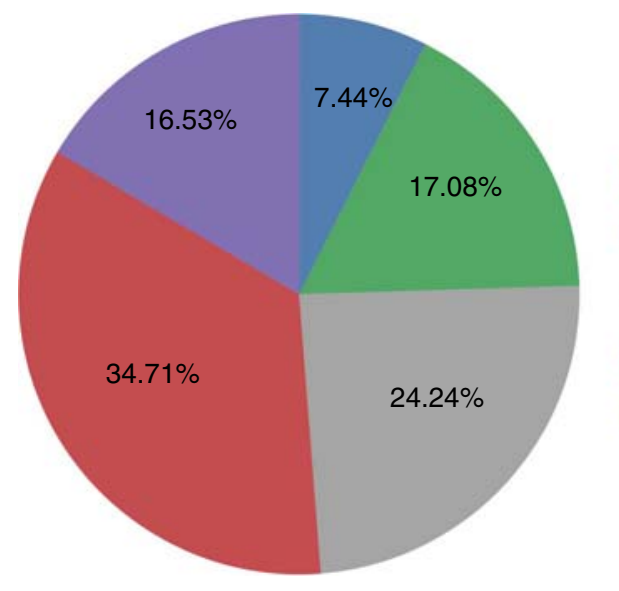

Rural poverty alleviation

Strongly disagree

Disagree

Neutral

Agree

Strongly agree

2605

Figure 3.

Farmer

entrepreneurship improves rural living conditions

\section{Conclusions, study limitations and future outlook}

Despite the fast growth of the Chinese economy in the past several decades, leading to many villages and small towns becoming more urbanized, the effect of RP on the living standards of many rural dwellers continues to attract attention for the central government and other stakeholders in the country on how to solve it. This paper, therefore, examines the relation between entrepreneurship among farmers and RP alleviation in China, using 363 survey data from Guangxi and Zhejiang provinces. SEM using AMOS 21.0, and Statistical Package for Social Sciences (IBM SPSS) version 20.0 was employed for the data analysis. Three capabilities of farm entrepreneurs, namely, educational, economic and socio-cultural, were identified and used to measure the quality of human life of respondents on a five-point Likert scale, based on four tested hypotheses.

The findings show that SSC have the strongest effect on growth of farmer entrepreneurship $(\beta=0.42, t=10.75$ and $\beta=0.39, t=8.26)$, followed by economic capabilities $(\beta=0.10, t=2.45$ and $\beta=0.28, t=6.10)$, while education capabilities negatively impacted the quantitative growth of farmer entrepreneurship $(\beta=-0.31$, $t=-12.49)$ but positively impacted qualitative growth $(\beta=0.22, t=5.29)$. The effect of the qualitative growth of farmer entrepreneurship on RP is significant and positive $(\beta=0.70$, $t=19.53)$, as is the effect of the quantitative growth of farmer entrepreneurship on RP ( $\beta=0.12, t=2.32$ ). Furthermore, the study reveals that approximately 83 percent of the youth aged between 16 and 59 years are engaged in farmer entrepreneurship; this is an indication that youth employment opportunities exist in rural China. In summary, the study found that there is a significant relationship between farmer entrepreneurship and RP alleviation in China. This finding, although its main focus is on the relation between entrepreneurship among farmers and RP, appears to be similar to the finding of Li et al. (2016), who studied on how to alleviate targeted poverty in China.

The main policy implication of the study is that RP as a multidimensional phenomenon in China requires a multitasked approach to solve it sustainably. Therefore, the Government of China should make great efforts to promote farmer entrepreneurship in the rural areas where the majority of the populace are farmers. This can serve as a "bottom-up" approach toward complementing the targeted poverty alleviation strategies that already exist. In addition, the government should lay more emphasis on promoting national farmer entrepreneurship policy to promote farmers' skills training programs, to help the rural farmers themselves create more agricultural jobs that will then impact positively on poverty. This can help China deepen rural reforms by strengthening rural farmers' 
capabilities in education, economic, and socio-cultural values, to increase farmer entrepreneurial activities, achieve the goal of alleviating poverty and improvement of rural living conditions and finally help attain China's dream of having a moderately prosperous society with Chinese characteristics in the nearest future.

This study has some limitations. First, the use of data from four communities in two provinces tends to limit the ability to generalize the findings of the study. Second, despite the usefulness and strength of the data, which presents an improvement in data collection and analysis, the survey did not collect information on non-farm entrepreneurs, preventing the opportunity to compare findings of both farm and non-farm entrepreneurs. In the future, studies should include more poverty-stricken provinces in China, and both farm and non-farm entrepreneurs, in order to compare the findings and reach a generalized conclusion based on nationally representative data.

\section{References}

Aaberge, R. and Brandolini, A. (2015), "Multidimensional poverty and inequality", in Anthony, B.A. and François, B. (Eds), Handbook of Income Distribution, Elsevier, Amsterdam, pp. 141-216.

Acs, Z.J., Arenius, P., Hay, M. and Minniti, M. (2005), Global Entrepreneurship Monitor 2004 Executive Report, Babson College and London Business School, Wellesley, MA and London.

Alkire, S. and Santos, M.E. (2014), "Measuring acute poverty in the developing world: robustness and scope of the multidimensional poverty index", World Development, Vol. 59, pp. 251-274, doi: 10.1016/j.worlddev.2014.01.026.

Ansoms, A. and McKay, A. (2010), "A quantitative analysis of poverty and livelihood profiles: the case of rural Rwanda", Food Policy, Vol. 35 No. 6, pp. 584-598.

Appadurai, A. (2004), "The capacity to aspire: culture and the terms of recognition”, in Rao, V. and Walton, M. (Eds), Culture and Public Action, The World Bank, Washington, DC, pp. 59-84.

Aryee, S., Budhwar, P.S. and Chen, Z.X. (2002), "Trust as a mediator of the relationship between organizational justice and work outcomes: test of a social exchange model", Journal of Organizational Behavior, Vol. 23 No. 3, pp. 267-285.

Aterido, R. and Hallward-Driemeier, M. (2011), "Whose business is it anyway?", Small Business Economics, Vol. 37 No. 4, pp. 443-464.

Bagozzi, R.P. and Youjae, Y. (1988), "On the evaluation of structural equation models”, Journal of the Academy of Marketing Science, Vol. 16 No. 1, pp. 74-94.

Bao, H., Cen, Y., Peng, Y. and Yuan, D. (2016), "Entrepreneurship and intervention strategies of land-lost farmers in urbanization process of Zhejiang Province", Public Personnel Management, Vol. 45 No. 1, pp. 37-57.

Baron, R.A., Mueller, B.A. and Wolfe, M.T. (2016), "Self-efficacy and entrepreneurs' adoption of unattainable goals: the restraining effects of self-control", Journal of Business Venturing, Vol. 31 No. 1, pp. 55-71.

Bentler, P.M. (1990), "Comparative fit indexes in structural models", Psychological Bulletin, Vol. 107 No. 2, pp. 238-246.

Bentler, P.M. (1992), "On the fit of models to covariances and methodology to the bulletin", Psychological Bulletin, Vol. 112 No. 3, pp. 400-404.

Birthal, P.S., Roy, D. and Negi, D.S. (2015), "Assessing the impact of crop diversification on farm poverty in India”, World Development, Vol. 72, pp. 70-92, doi: 10.1016/j.worlddev.2015.02.015.

Bruton, G.D., Ketchen, D.J. and Ireland, R.D. (2013), "Entrepreneurship as a solution to poverty”, Journal of Business Venturing, Vol. 28 No. 6, pp. 683-689.

Cai, D., Song, Q., Ma, S., Dong, Y. and Xu, Q. (2018), "The relationship between credit constraints and household entrepreneurship in China", International Review of Economics \& Finance, doi: 10.1016/j.iref.2018.1003.1024.

Carmines, E.G. and Zeller, R.A. (1979), Reliability and Validity Assessment, Sage, Thousand Oaks, CA. 
Carter, S. (1999), "Multiple business ownership in the farm sector: assessing the enterprise and employment contributions of farmers in Cambridgeshire", Journal of Rural Studies, Vol. 15 No. 4, pp. 417-429.

Carter, S., Kuhl, A., Marlow, S. and Mwaura, S. (2017), "Households as a site of entrepreneurial activity", Foundations and Trends in Entrepreneurship, Vol. 13 No. 2, pp. 81-190.

Chowdhury, T.A. and Mukhopadhaya, P. (2012), "Assessment of multidimensional poverty and effectiveness of microfinance-driven government and NGO projects in the rural Bangladesh", The Journal of Socio-Economics, Vol. 41 No. 5, pp. 500-512.

de Brauw, A., Li, Q., Liu, C., Rozelle, S. and Zhang, L. (2008), "Feminization of agriculture in China? Myths surrounding women's participation in farming", The China Quarterly, Vol. 194, pp. 327-348, doi: 10.1017/S0305741008000404.

Démurger, S. and Fournier, M. (2011), "Poverty and firewood consumption: a case study of rural households in northern China", China Economic Review, Vol. 22 No. 4, pp. 512-523.

Dhahri, S. and Omri, A. (2018), "Entrepreneurship contribution to the three pillars of sustainable development: what does the evidence really say?”, World Development, Vol. 106, pp. 64-77.

Ferreira, J.J.M., Fernandes, C.I., Alves, H. and Raposo, M.L. (2015), "Drivers of innovation strategies: testing the Tidd and Bessant (2009) model", Journal of Business Research, Vol. 68 No. 7, pp. 1395-1403.

Fitz-Koch, S., Nordqvist, M., Carter, S. and Hunter, E. (2018), "Entrepreneurship in the agricultural sector: a literature review and future research opportunities", Entrepreneurship Theory and Practice, Vol. 42 No. 1, pp. 129-166.

Fornell, C. and Larcker, D.F. (1981), "Evaluating structural equation models with unobservable variables and measurement error", Journal of Marketing Research, Vol. 18 No. 1, pp. 39-50.

Ge, X., Li, Y., Luloff, A.E., Dong, K. and Xiao, J. (2015), "Effect of agricultural economic growth on sandy desertification in Horqin Sandy Land", Ecological Economics, Vol. 119, pp. 53-63, doi: 10.1016/j.ecolecon.2015.08.006.

Gerbing, D.W. and Anderson, J.C. (1988), "An updated paradigm for scale development incorporating unidimensionality and its assessment", Journal of Marketing Research, Vol. 25 No. 2, pp. 186-192.

Gökovali, U. (2013), "Everyone's own poverty: gendering poverty alleviation policies in Turkey", Women's Studies International Forum, Vol. 41, pp. 65-75.

Gómez-Grass, J.M., Mira-Solves, I. and Martínez-Mateo, J. (2010), "Determinants of entrepreneurship: an overview", International Journal of Business Environment, Vol. 3 No. 1, pp. 1-14.

Greco, G., Skordis-Worrall, J., Mkandawire, B. and Mills, A. (2015), "What is a good life? Selecting capabilities to assess women's quality of life in rural Malawi”, Social Science \& Medicine, Vol. 130, pp. 69-78, doi: 10.1016/j.socscimed.2015.01.042.

Hair, T.F., Black, W.C., Babin, B.J., Anderson, R.E. and Tatham, R.L. (2006), Multivariate Data Analysis, Pearson Prentice Hall, Upper Saddle River, NJ.

Harbi, S.E. and Anderson, A.R. (2010), "Institutions and the shaping of different forms of entrepreneurship", The Journal of Socio-Economics, Vol. 39 No. 3, pp. 436-444.

Hoang, T.X., Pham, C.S. and Ulubaşoğlu, M.A. (2014), "Non-farm activity, household expenditure, and poverty reduction in rural Vietnam: 2002-2008", World Development, Vol. 64, pp. 554-568, doi: 10.1016/j.worlddev.2014.06.027.

Hofstede, G. (1980), Culture's Consequences: International Differences in Work-Related Values, Sage, Thousand Oaks, CA.

Huang, Y. (2016), "Understanding China's belt \& road initiative: motivation, framework and assessment”, China Economic Review, Vol. 40, pp. 314-321, available at: https://doi.org/10.1016/j. chieco.2016.07.007

Hunter, R. (1904), Poverty, Macmillan, New York, NY.

Kahan, D. (2012), Entrepreneurship in Farming, Food and Agriculture Organization of the United Nations, Rome. 
Kantur, D. (2016), "Strategic entrepreneurship: mediating the entrepreneurial orientation-performance link", Management Decision, Vol. 54 No. 1, pp. 24-43.

Kong, R., Turvey, C.G., Channa, H. and Peng, Y. (2015), "Factors affecting farmers' participation in China's group guarantee lending program”, China Agricultural Economic Review, Vol. 7 No. 1, pp. 45-64.

Li, L. and $\mathrm{Wu}, \mathrm{X}$. (2014), "Housing price and entrepreneurship in China", Journal of Comparative Economics, Vol. 42 No. 2, pp. 436-449.

Li, Y., Su, B. and Liu, Y. (2016), "Realizing targeted poverty alleviation in China”, China Agricultural Economic Review, Vol. 8 No. 3, pp. 443-454.

Li, Y., Liu, Y., Long, H. and Cui, W. (2014), "Community-based rural residential land consolidation and allocation can help to revitalize hollowed villages in traditional agricultural areas of China: evidence from Dancheng County, Henan Province”, Land Use Policy, Vol. 39 No. 1, pp. 188-198.

Lin, S. and Gaubatz, P. (2015), "New Wenzhou: migration, metropolitan spatial development and modernity in a third-tier Chinese model city", Habitat International, Vol. 50, pp. 214-225, doi: 10.1016/j.habitatint.2015.08.040.

McElwee, G. (2004), “A segmentation framework for the farm sector", 3rd Rural Entrepreneurship Conference, University of Paisley, Paisley, September 20-24.

McElwee, G. (2006), "Farmers as entrepreneurs: developing competitive skills", Journal of Developmental Entrepreneurship, Vol. 11 No. 3, pp. 187-206.

Ma, T., Li, C., Lu, Z. and Bao, Q. (2015), "Rainfall intensity-duration thresholds for the initiation of landslides in Zhejiang Province, China", Geomorphology, Vol. 245, pp. 193-206, doi: 10.1016/j. geomorph.2015.05.016.

Martin, S.L. and Javalgi, R.G. (2016), "Entrepreneurial orientation, marketing capabilities and performance: the moderating role of competitive intensity on Latin American international new ventures", Journal of Business Research, Vol. 69 No. 6, pp. 2040-2051.

Martinez, C., Cummings, M.E. and Vaaler, P.M. (2015), "Economic informality and the venture funding impact of migrant remittances to developing countries", Journal of Business Venturing, Vol. 30 No. 4, pp. 526-545.

May, J. (1999), Poverty and Inequality in South Africa: Meeting the Challenge, D. Philip, Cape Town.

Meng, L. and Zhao, M.Q. (2017), "Permanent and temporary rural-urban migration in China: evidence from field surveys".

Mihai, M., Ţiţan, E. and Manea, D. (2015), "Education and poverty", Procedia Economics and Finance, Vol. 32, pp. 855-860, doi: 10.1016/S2212-5671(15)01532-4.

Mohapatra, S., Rozelle, S. and Goodhue, R. (2007), "The rise of self-employment in rural China: development or distress?", World Development, Vol. 35 No. 1, pp. 163-181.

Montalvo, J.G. and Ravallion, M. (2010), "The pattern of growth and poverty reduction in China", Journal of Comparative Economics, Vol. 38 No. 1, pp. 2-16.

Nagler, P. and Naudé, W. (2017), "Non-farm entrepreneurship in rural sub-Saharan Africa: new empirical evidence”, Food Policy, Vol. 67, pp. 175-191, doi: 10.1016/j.foodpol.2016.09.019.

Ngoasong, M.Z. and Kimbu, A.N. (2016), "Informal microfinance institutions and development-led tourism entrepreneurship", Tourism Management, Vol. 52, pp. 430-439, doi: 10.1016/j. tourman.2015.07.012.

Nunnally, J.C. (1978), Psychometric Theory, McGraw-Hill, New York, NY.

Nussbaum, M.C. (2011), Creating Capabilities: The Human Development Approach, Harvard University Press, Cambridge, MA.

Pyysiäinen, J., Anderson, A., McElwee, G. and Vesala, K. (2005), "Developing the entrepreneurial skills of farmers: some myths explored", International Journal of Entrepreneurial Behavior \& Research, Vol. 12 No. 1, pp. 21-39.

Ravallion, M. (2011), "On multidimensional indices of poverty", The Journal of Economic Inequality, Vol. 9 No. 2, pp. 235-248. 
Ravallion, M. and Chen, S. (2007), "China's (uneven) progress against poverty”, Journal of Development Economics, Vol. 82 No. 1, pp. 1-42.

Robeyns, I. (2005), "The capability approach: a theoretical survey", Journal of Human Development, Vol. 6 No. 1, pp. 93-114.

Rowntree, B.S. (1901), Poverty, a Study of Town Life, Macmillan, London.

Rudmann, C. (2008), Entrepreneurial Skills and their Role in Enhancing the Relative Independence of Farmers Results and Recommendations from the Research Project Developing Entrepreneurial Skills of Farmers, Research Institute of Organic Agriculture FIBL, Frick.

Saxena, S. (2012), "Problems faced by rural entrepreneurs and remedies to solve it", Journal of Business and Management, Vol. 3 No. 1, pp. 23-29.

Schumpeter, J.A. (1934), The Theory of Economic Development, Harvard University Press, Cambridge, MA.

Sen, A. (1981), Poverty and Famines: An Essay on Entitlement and Deprivation, Oxford University Press, Oxford.

Sen, A. (2000), Freedom, Rationality, and Social Choice: The Arrow Lectures and Other Essays, Oxford University Press, Oxford.

Sen, A.K. (1985), Commodities and Capabilities, North-Holland Sole Distributors for the U.S.A. and Canada, Elsevier Science Publishing, New York, NY.

Seuneke, P., Lans, T. and Wiskerke, J.S.C. (2013), "Moving beyond entrepreneurial skills: key factors driving entrepreneurial learning in multifunctional agriculture", Journal of Rural Studies, Vol. 32 No. 4, pp. 208-219.

Shane, S. (1993), "Cultural influences on national rates of innovation”, Journal of Business Venturing, Vol. 8 No. 1, pp. 59-73.

Shane, S. and Venkataraman, S. (2000), "The promise of entrepreneurship as a field of research", Academy of Management Review, Vol. 25 No. 1, pp. 217-226.

Sharma, M., Tiwari, R. and Sharma, J. (2010), Entrepreneurship in Livestock and Agriculture, CBS Publishers \& Distributors, New Delhi.

She, Y., Shen, L., Jiao, L., Zuo, J., Tam, V.W.Y. and Yan, H. (2018), "Constraints to achieve infrastructure sustainability for mountainous townships in China”, Habitat International, Vol. 73, pp. 65-78, doi: 10.1016/j.habitatint.2018.01.009.

Shepherd, D.A. (2015), "Party On! A call for entrepreneurship research that is more interactive, activity based, cognitively hot, compassionate, and prosocial", Journal of Business Venturing, Vol. 30 No. 4, pp. 489-507.

Sutter, C., Bruton, G.D. and Chen, J. (2018), "Entrepreneurship as a solution to extreme poverty: a review and future research directions", Journal of Business Venturing, doi: 10.1016/j. jbusvent.2018.06.003.

Syed, A.R., Yasir, A. and Farhan, M. (2012), "Role of agriculture in economic growth in Pakistan", International Research Journal of Finance and Economics, Vol. 83, pp. 180-186.

Tarabini, A. and Jacovkis, J. (2012), “The poverty reduction strategy papers: an analysis of a hegemonic link between education and poverty", International Journal of Educational Development, Vol. 32 No. 4, pp. 507-516.

Thurik, A.R., Carree, M.A., van Stel, A. and Audretsch, D.B. (2008), "Does self-employment reduce unemployment?”, Journal of Business Venturing, Vol. 23 No. 6, pp. 673-686.

Tisdell, C. (2009), "Economic reform and openness in China: China's development policies in the last 30 years", Economic Analysis and Policy, Vol. 39 No. 2, pp. 271-294.

Tobias, J.M., Mair, J. and Barbosa-Leiker, C. (2013), "Toward a theory of transformative entrepreneuring: poverty reduction and conflict resolution in Rwanda's entrepreneurial coffee sector", Journal of Business Venturing, Vol. 28 No. 6, pp. 728-742.

Tortajada, C. (2016), "Policy dimensions of development and financing of water infrastructure: the cases of China and India”, Environmental Science \& Policy, Vol. 64, pp. 177-187, doi: 10.1016/j. envsci.2016.07.001. 

Development, Oxford University Press, Oxford, United Nations Development Programme.

Van Rooyen, C.J. (2014), “Towards 2050: trends and scenarios for African agribusiness”, International Food and Agribusiness Management Review, Vol. 17, Special Issue B, pp. 19-39.

Venot, J.P. (2016), "A success of some sort: social enterprises and drip irrigation in the developing world”, World Development, Vol. 79, pp. 69-81, doi: 10.1016/j.worlddev.2015.11.002.

Verheul, I., Wennekers, A.R.M., Audretsch, A.B. and Thurik, A.R. (2002), "An eclectic theory of entrepreneurship", in Audretsch, D.B., Thurik, A.R., Verheul, I. and Wennekers, A.R.M. (Eds), Entrepreneurship: Determinants and Policy in a European-US Comparison, Kluwer Academic Publishers, Boston, MA and Dordrecht, pp. 11-81.

Verheul, I., Block, J., Burmeister-Lamp, K., Thurik, R., Tiemeier, H. and Turturea, R. (2015), “ADHD-like behavior and entrepreneurial intentions”, Small Business Economics, Vol. 45 No. 1, pp. 85-101.

Walter, S.G. and Block, J.H. (2016), "Outcomes of entrepreneurship education: an institutional perspective”, Journal of Business Venturing, Vol. 31 No. 2, pp. 216-233.

Wan, G. and Zhang, Y. (2018), "The direct and indirect effects of infrastructure on firm productivity: evidence from Chinese manufacturing", China Economic Review, Vol. 49, pp. 143-153, doi: 10.1016/j.chieco.2017.04.010.

Wang, S., Li, Z. and Ren, Y. (2004), The 8-7 National Poverty Reduction Program in China - The National Strategy and its Impact: A Case Study from Reducing Poverty, Sustaining Growth, Scaling up Poverty Reduction: A Global Learning Process and Conference, World Bank, Washington, DC.

Wang, Y. and Chen, Y. (2016), "Using VPI to measure poverty-stricken villages in China", Social Indicators Research, Vol. 133 No. 3, pp. 833-857.

Weaver, R.R., Lemonde, M., Payman, N. and Goodman, W.M. (2014), "Health capabilities and diabetes self-management: the impact of economic, social, and cultural resources", Social Science \& Medicine, Vol. 102 No. 2, pp. 58-68.

Wen, Y., Tang, M., Sun, D., Zhu, H., Wei, J., Chen, F. and Tang, L. (2012), "Influence of climatic factors and soil types on seed weight and oil content of Jatropha Curcas in Guangxi, China", Procedia Environmental Sciences, Vol. 12, pp. 439-444, doi: 10.1016/j.proenv.2012.01.301.

World Bank (2013), "The state of the poor: where are the poor and where are they poorest", available at: www.thehinducentre.com/multimedia/archive/02643/State_of_the_poor_2643567a.pdf (accessed June 20, 2015).

Xinhua News (2015), "Poverty line in China”, available at: http://articles.economictimes.indiatimes.com/20 15-12-15/news/69062082_1_poverty-line-poverty-alleviation-xinhua (accessed January 6, 2016).

Yanya, M., Abdul-Hakim, R. and Abdul-Razak, N.A. (2013), "Does entrepreneurship bring an equal society and alleviate poverty? Evidence from Thailand", Procedia - Social and Behavioral Sciences, Vol. 91, pp. 331-340, doi: 10.1016/j.sbspro.2013.08.430.

Ying, X. and Min, L. (2011), "Research on farmers' production willingness of safe agricultural products and its influence factors: an empirical analysis in China", Energy Procedia, Vol. 5, pp. 53-58.

Yuan, D., Zhang, X., Bao, H. and Fu, Y. (2017), "The self-employment of the industry choices of dispossessed farmers in China", Journal of Rural Studies, Vol. 55, pp. 143-156, available at: https://doi.org/10.1016/j.jrurstud.2017.08.006

Yuan, F. and Zhou, J. (2015), "Effects of cultural power distance on group creativity and individual group member creativity", Journal of Organizational Behavior, Vol. 36 No. 7, pp. 990-1007.

Zhai, F. (2018), "China's belt and road initiative: a preliminary quantitative assessment", Journal of Asian Economics, Vol. 55, pp. 84-92, available at: https://doi.org/10.1016/j.asieco.2017.12.006

Zhao, J. and Tang, J. (2018), "Understanding agricultural growth in China: an international perspective", Structural Change and Economic Dynamics, doi: 10.1016/j.strueco.2018.03.006.

Zheng, L. and Zhao, Z. (2017), "What drives spatial clusters of entrepreneurship in China? Evidence from economic census data", China Economic Review, Vol. 46, pp. 229-248, doi: 10.1016/j. chieco.2017.09.014. 


\begin{tabular}{|c|c|c|c|}
\hline Item & Definition & Source & \\
\hline y1 & More farmers are becoming entrepreneurs & Sen (2000) & \\
\hline $\mathrm{y} 2$ & More enterprises are being founded by villagers & & 2611 \\
\hline y3 & $\begin{array}{l}\text { Enterprises founded by villagers offer more funds to support the development } \\
\text { of the village }\end{array}$ & & \\
\hline $\mathrm{y} 4$ & Enterprises founded by villagers are getting better every time & & \\
\hline y5 & More children now go to school & & \\
\hline y6 & Children's education condition is getting better & & \\
\hline y7 & The education children receive is increasingly high & & \\
\hline y8 & I have more access to high market knowledge/information & & \\
\hline y9 & I have access to more knowledge in technology & Nussbaum (2011) & \\
\hline y10 & I have access to more knowledge in management & & \\
\hline y11 & I have the opportunity to receive more training & & \\
\hline $\mathrm{y} 12$ & The medical facilities in the village are improving & & \\
\hline y13 & The medical attention level in the village is getting higher all the time & & \\
\hline y14 & I have more chances to make more money in the village & & \\
\hline y15 & I feel that the family income is getting higher than before & & \\
\hline y16 & Village management affairs are becoming more open and transparent & Aryee et al. (2002) & \\
\hline y17 & Village decision-making affairs are becoming more democratic & & \\
\hline y18 & $\begin{array}{l}\text { Community members are increasingly willing to express their ideas about the } \\
\text { affairs of the village }\end{array}$ & & $\begin{array}{l}\text { Table AI. } \\
\text { Research }\end{array}$ \\
\hline y19 & Villagers' leisure activities are becoming more abundant & & questionnaire \\
\hline
\end{tabular}

\begin{abstract}
About the authors
Eric Yaw Naminse is a young scholar from Ghana-West Africa. He has a multicultural background which enables him to understand issues from a global perspective. He received his Bachelor of Science (BSc) Degree from the University for Development Studies (UDS) in Ghana, Tamale in 2004, and subsequently gained scholarship from the United States Agency for International Development (USAID) to pursue Master of Agribusiness (MAB) Degree in Texas A\&M University in 2008. He then had his PhD Degree in Management Science and Engineering from Jiangsu University in the People's Republic of China in 2016. His research interest areas include agribusiness strategic management, rural entrepreneurship and poverty alleviation in developing countries. Eric Yaw Naminse is the corresponding author and can be contacted at: yawric@yahoo.com

Jincai Zhuang is a Professor and Deputy Dean in the School of Management in Jiangsu University, P.R. China. He received his $\mathrm{PhD}$ Degree in Economics from Sichuan University, China. His research focuses on entrepreneurship, rural sociology and development, and mechanisms to reduce the plight of migrant workers in Chinese cities.

Fangyang Zhu is a Professor and Dean in the School of Economics and Management in Qinzhou University, P.R. China. His research interest areas are port logistics and supply chain management.
\end{abstract}

For instructions on how to order reprints of this article, please visit our website: 